\title{
DATING OF ROSS ICE SHELF CORES BY GHEMICAL ANALYSIS
}

\author{
By Mighael M. Herron and Chester C. Langway, Jr \\ (Ice Core Laboratory, Department of Geological Sciences, State University of New York at \\ Buffalo, 4240 Ridge Lea Road, Amherst, New York 14226, U.S.A.)
}

\begin{abstract}
Seasonal variations in sodium concentrations have been measured on surface-pit snow samples and on firn and ice core samples from the Ross Ice Shelf, Antarctica. Site locations include J-9

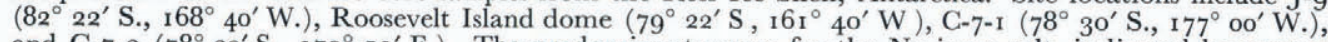
and C-7-3 ( $78^{\circ} 20^{\prime} \mathrm{S} ., 179^{\circ} 5 \mathrm{I}^{\prime} \mathrm{E}$.). The predominant source for the $\mathrm{Na}$ is sea salt, indicated by greater concentration levels at seaward sites. Al concentrations of the order of only $10^{-9} \mathrm{~g} / \mathrm{g}$ show that the input of continental dust is comparable to that at inland Antarctic locations, and that dust contributes only a negligibly small fraction of the $\mathrm{Na}$ on the shelf. Maximum Na concentrations occur in the winter or early spring, as is the case for Greenland ice. The annual accumulation-rate at $\mathrm{J}-9$, determined by counting Na concentration peaks with depth, is $90 \mathrm{~kg} \mathrm{~m}^{-2}$ year -1 , in agreement with rates determined radiometrically. Annual cycles in $\mathrm{Na}$ concentration are also detectable at depth in the J-9 ice core. It is suggested that $\mathrm{Na}$ concentration is a useful diagnostic criterion for distinguishing between East Antarctic ice $\left(\mathrm{IO}^{-8} \mathrm{~g} \mathrm{Na} / \mathrm{g}\right)$, West Antarctic ice $\left(30 \times 10^{-9} \mathrm{~g} \mathrm{Na} / \mathrm{g}\right)$, and ice that fell as snow on the shelf itself $\left(>30 \times 10^{-9} \mathrm{~g} \mathrm{Na} / \mathrm{g}\right)$. The transition between snow that is chemically characteristic of the ice-shelf regime to snow of an inland regime is expected to occur near the $500 \mathrm{~m}$ elevation contour. This position is up to $200 \mathrm{~km}$ inland of the grounding line. A model is presented for the large-scale decrease in $\mathrm{Na}$ concentration with distance inland within the ice-shelf regime. Since deeper ice in Ross Ice Shelf cores originated generally further from the ocean, the up-stream origin of shelf ice may be estimated from the chemical profile. The Little America V ice-core chemistry profile shows no discontinuity as would be expected if a recent surge of West Antarctic ice had occurred.
\end{abstract}

RÉsumé. Rotation de carottes du Ross Ice Shelf par analyses chimiques. Les variations annuelles des concentrations en sodium ont été mesurées sur des échantillons de neige prélevés dans des sondages superficiels et sur des échantillons de glace et de névé issus du Ross Ice Shelf, Antarctique. Les points de prélèvement comprennent J-9 $\left(82^{\circ} 22^{\prime}\right.$ S., $168^{\circ} 40^{\prime}$ W. $)$, Roosevelt Island $\left(79^{\circ} 22^{\prime}\right.$ S., $161^{\circ} 40^{\prime}$ W. $)$, C- $7-1$ ( $78^{\circ} 30^{\prime}$ S., ${ }_{1} 77^{\circ} 0^{\prime}$ W. $)$, et C- $7-3$ ( $78^{\circ} 20^{\prime}$ S., $179^{\circ} 5 \mathrm{I}^{\prime}$ E.). La source principale de $\mathrm{Na}$ est le sel marin, comme l'indique les niveaux de plus grandes concentrations dans les sites face à la mer. Les concentrations en aluminium de l'ordre de seulement $10^{-9} \mathrm{~g} / \mathrm{g}$ montrent que l'apport des poussières continentales est comparable à ce qu'il est dans les sites continentaux de l'Antarctique et que ces poussières ne contribuent que pour une fraction négligeable au $\mathrm{Na}$ dans la plateforme. Les plus grandes concentrations en Na se produisent en hiver ou au début du printemps comme c'est le cas pour la glace du Groenland. Le taux annuel d'accumulation en J-9 déterminé en comptant les maximums de concentration en $\mathrm{Na}$ quand on s'enfonce en profondeur, est de $90 \mathrm{~kg} / \mathrm{m}^{2} / \mathrm{an}$, résultats en accord avec les taux déterminés par radiométrie. Les cycles annuels de concentration en $\mathrm{Na}$ sont aussi détectables en profondeur dans les carottes de glace J-9. On suggère que la concentration en $\mathrm{Na}$ est un critère utilisable pour distinguer entre la glace de l'Est Antarctique $\left(10^{-8} \mathrm{~g} \mathrm{Na} / \mathrm{g}\right)$, la glace de l'Ouest Antarctique $\left(30 \times 10^{-9} \mathrm{~g} \mathrm{Na} / \mathrm{g}\right)$ et la glace qui est tombée sous forme de neige sur la plateforme elle-même $\left(>30 \times 10^{-9} \mathrm{~g} \mathrm{Na} / \mathrm{g}\right)$. La transition entre la neige, qui est chimiquement caractéristique du régime de la plateforme, à la neige d'un régime continental s'établie pense-t'on, aux environs de la ligne du niveau $500 \mathrm{~m}$. Elle se situe à plus de $200 \mathrm{~km}$ vers l'intérieur à partir de la ligne de décollement. On présente un modèle de la décroissance à une grande échelle de la concentration en $\mathrm{Na}$ quand on va vers l'intérieur en restant dans le régime de la plateforme. Comme la glace plus profonde dans les échantillons du Ross Ice Shelf est en général d'origine océanique, on peut déceler les glaces venues du continent à partir du profil chimique. Les profils chimiques de carottes de glace de Little America V ne montrent pas des discontinuités auxquelles on pourrait s'attendre s'il y avait eu une récente crue de l'Ouest Antarctique.

Zusammenfassung. Datierung von Kernen aus dem Ross Ice Shelf durch chemische Analyse. An Schneeproben aus oberflächlichen Schächten sowie an Firn- und Eiskernen aus dem Ross Ice Shelf, Antarktika, wurden die jahreszeitlichen Schwankungen der Sodium-Konzentration gemessen. Die Proben stammen von folgenden

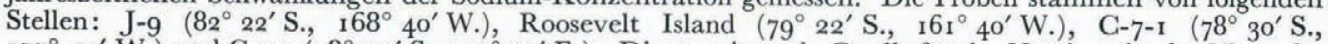
$177^{\circ} 00^{\prime}$ W. $)$ und C-7-3 $\left(78^{\circ} 20^{\prime}\right.$ S., $179^{\circ} 5 \mathrm{I}^{\prime}$ E. $)$. Die vorwiegende Quelle für das Natrium ist das Meersalz, was sich aus dem höheren Konzentrationsniveau in seewärts gelegenen Stellen ergibt. AluminiumKonzentrationen in der Grössenordnung von nur $10^{-9} \mathrm{~g} / \mathrm{g}$ zeigen, dass der Zustrom kontinentalen Staubes vergleichbar mit dem an innerantarktischen Stellen ist und dass Staub nur einen vernachlässigbaren Bruchteil des Natriums auf dem Schelfeis liefert. Die maximalen Na-Konzentrationen treten im Winter oder frühen Frühling auf, - genau wie im Grönlandeis. Die jährliche Akkumulationsrate in J-9, gewonnen aus Zählungen der Na-Konzentrationsspitzen nach der Tiefe, beträgt $90 \mathrm{~kg} \mathrm{~m}^{-2}$ pro Jahr, was mit radiometrisch gewonnenen Werten übereinstimmt. Jahreszyklen der Na-Konzentration lassen sich auch in den tiefen Teilen des J-9 Eiskernes feststellen. Die Na-Konzentration erweist sich als brauchbares diagnostisches Kriterium zur Unterscheidung von ostantarktischem Eis $\left(10^{-8} \mathrm{~g} \mathrm{Na} / \mathrm{g}\right)$, westantarktischem Eis $\left(30 \times 10^{-9}\right.$ $\mathrm{g} \mathrm{Na} / \mathrm{g}$ ) und Eis, das als Schnee auf dem Schelfeis selbst fiel $\left(>30 \times 10^{-9} \mathrm{~g} \mathrm{Na} / \mathrm{g}\right)$. Der Übergang von Schnee, der chemisch charakteristisch für das Schelfeissystem ist, zu Schnee eines landeinwärtigen Systems, 
dürfte nahe der $500 \mathrm{~m}$ Höhenlinie liegen. Diese Position liegt bis zu $200 \mathrm{~km}$ landeinwärts der Aufsetzlinie. Es wird ein Modell für die grossräumige Abnahme der Na-Konzentration mit dem Abstand vom Schelfeisrand vorgelegt. Da tieferes Eis in der Ross Ice Shelf im allgemeinen von ozeanfernen Bereichen stammt, kann der Zustromcharakter von Schelfeis aus dem chemischen Profil abgeschätzt werden. Das chemische Profil des Eiskerns von Little America V zeigt keine Diskontinuität, die zu erwarten wäre, falls in jüngster Zeit ein Ausbruch des westantarktischen Eises stattgefunden hätte.

\section{INTRODUGTION}

Within the last few thousand years, a rapid outflow of ice from West Antarctica may have lowered surface elevations by as much as $100 \mathrm{~m}$ (Johnsen and others, 1972; Hughes, 1973). Such an event would be reflected in the recent flow history of the Ross Ice Shelf which serves to drain much of the West Antarctic ice sheet (Giovenetto and Zumberge, 1967). By establishing the age and origin of deep ice within the shelf it is possible to reconstruct past ice movment for comparison with particle paths derived from geophysical and glaciological data.

The age and origin of deep Ross Ice Shelf ice may be estimated from glaciochemical data, particularly the vertical and horizontal variations in sea-salt concentrations. Sea salt is the dominant aerosol on the ice shelf. Sodium, the most abundant cation in sea-water, is a useful index element for that source. The identification of annual cycles in $\mathrm{Na}$ concentrations in Ross Ice Shelf cores allows an accurate determination of the recent annual accumulation-rate and the changes in thickness of annual layers with depth due to vertical strain, accumulationrate variations up-stream, and climatic factors. Continuous sampling will permit the dating of cores. The origin of deep ice may be estimated by matching $\mathrm{Na}$ concentrations at depth with equivalent up-stream surface values.

Surface $\mathrm{Na}$ concentrations are a function of geographic position on the shelf; the most pronounced effect of this is a dramatic decrease in concentration with distance from the ice front (Warburton and Linkletter, 1977). The concept of Antarctic glaciochemical regimes (Herron and Langway, unpublished) indicates that it is possible, on the basis of Na concentrations, to discriminate between ice from West Antarctica, ice from East Antarctica, and shelf ice. Since inland ice generally underlies shelf ice, it is possible to delineate the glaciochemical transition depth in Ross Ice Shelf (RIS) cores, to determine the inland source, and to detect any migration of the flow line dividing East and West Antarctic ice.

\section{SAMPLING AND ANALYTICAL PROCEDURES}

Sampling locations are shown in Figure I. Surface samples were collected from two-meterdeep pits located three kilometers south-west, three kilometers west, and ten kilometers south of station J-9, and from C-7-I under ultra-clean conditions previously described by Herron and others (1977). Ice core samples from J-9 include the $100 \mathrm{~m}$ long core drilled electromechanically in I974 (Rand, I975) and the I50-155 m core drilled thermally as part of the Ross Ice Shelf Project (RISP) in 1976 (Rand, 1977). Firn cores from C-7-1, C-7-3, and Roosevelt Island dome were also sampled (Langway and Herron, 1977). Ice core samples were prepared using the "dry core" cleaning procedure (Langway and others, I974). Firn core samples were prepared by cutting the material to an appropriate length with a bandsaw, mechanically trimming $0.5 \mathrm{~cm}$ from the ends with a precleaned stainless-steel chisel, and recoring with a $2.5 \mathrm{~cm}$ diameter precleaned stainless-steel tube. Comparative studies show that when samples are prepared with this procedure, chemical measurements are identical to those of duplicate channel samples from a pit wall. Concentrations of $\mathrm{Na}$ and $\mathrm{Al}$ were determined by flameless atomic absorption spectrophotometry using a Perkin-Elmer Model 503 AA and HGA-2 100 graphite furnace and an AS-I autosampler within a Class roo clean room. Most of the samples were diluted up to 50 times to bring their concentrations into the linear working range of these instruments. 


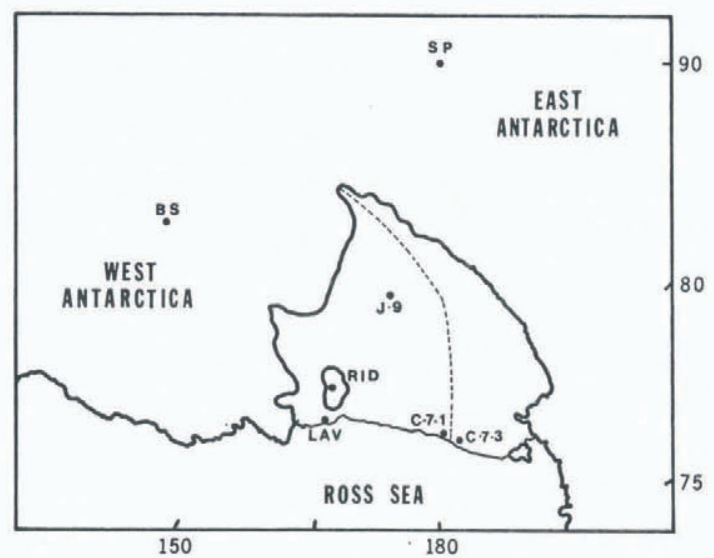

Fig. I. Map of the Ross Ice Shelf showing sampling locations. The dashed line represents the approximate division between East and West Antarctic ice-drainage regimes.

\section{Seasonal Variations}

The determination of annual accumulation-rates on the Ross Ice Shelf is difficult. Accumulation-rates determined by classical stratigraphic techniques and by measurements of gross $\beta^{-}$ activity differ considerabiy (Clausen and Dansgaard, 1977). The gross $\beta^{-}$technique is limited to a useful time period of about 25 years. Seasonal variations in the stable oxygen isotope are smoothed by vapor diffusion within a few years (Clausen and Dansgaard, r977). Various radiometric techniques for dating ice thousands of years old have not yet been investigated due to the lack of available deep ice-shelf samples (Stauffer and Moell, 1977).

Pronounced seasonal variations in chemical concentrations have been found in Greenland ice cores (Murozumi and others, I969; Koide and Goldberg, I971; Langway and others, I977; Herron and Langway, 1978). Sea salts, indexed by Cl and dust-corrected Na concentrations, exhibit distinct winter maxima when correlated with stable oxygen-isotope variations. The winter salt peaks are evidently due to the effect of severe winter storm systems that agitate the sea surface. Frequently, Na concentration peaks are very sharp compared to the more sinusoidal shape of the oxygen isotope peak, indicating that much of the sea salt input is in the form of distinct winter events, similar to that observed for Japanese rain by Tsunogoi (1975).

Sodium concentrations measured on samples from the pit ro km south of J-9 (Fig. 2a) show clear and regular cycles with an amplitude of about $70 \times 10^{-9} \mathrm{~g} / \mathrm{g}$. The cyclic accumulation-rate derived from the chemistry data and the pit density profile is $90 \mathrm{~kg} \mathrm{~m}^{-2}$. This agrees with the annual accumulation-rate determined for station J-9 by fission product (Clausen and Dansgaard, 1977) and ${ }^{210}$ Po dating studies (Koide and others, 1979) which confirms that the period of the cycles is one year. The samples were collected in late spring 1976, indicating that the initial concentration peak occurs in winter or early spring, as is the case in Greenland. Supporting evidence for a winter sea-salt maximum is shown in the pit profile from C-7-I (Fig. 2b) where Na concentration peaks and summer ice layers do not coincide. The annual accumulation-rate over the measured interval at C-7-I (Fig. 2c) is $130 \mathrm{~kg} \mathrm{~m}^{-2} \mathrm{a}^{-1}, 30 \%$ lower than measurements made 20 years ago by Crary and others (1962) for a station approximately $60 \mathrm{~km}$ inland of C-7-1, but in agreement with stake measurements made about $80 \mathrm{~km}$ inland of C-7-I (Heap and Rundle, 1964). The chemically-derived annual accumulation-rate at Roosevelt Island dome (Fig. 2d) is $160 \mathrm{~kg} \mathrm{~m}^{-2} \mathrm{a}^{-1}$, in good agreement with the general accumulation pattern (Bull, 1971). 


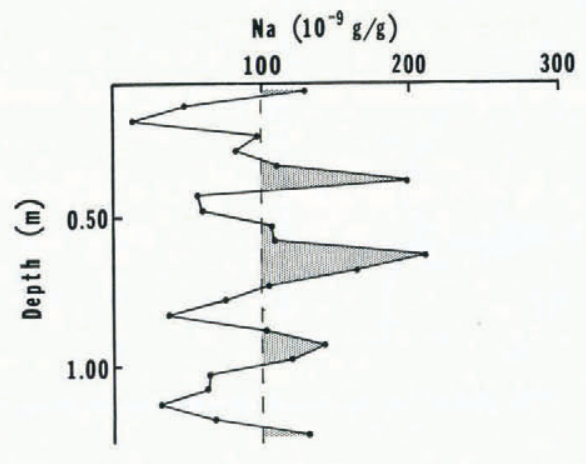

(a)

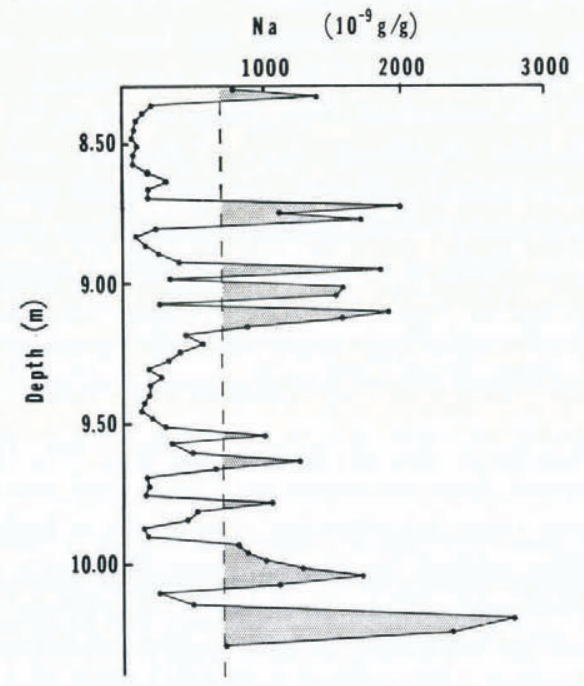

(c)

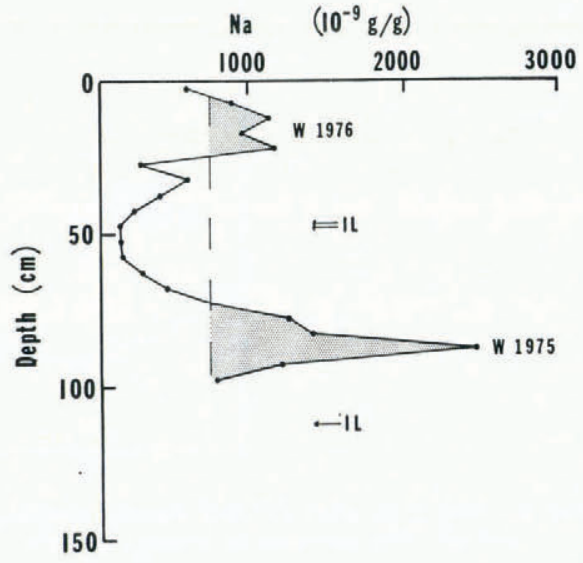

(b)

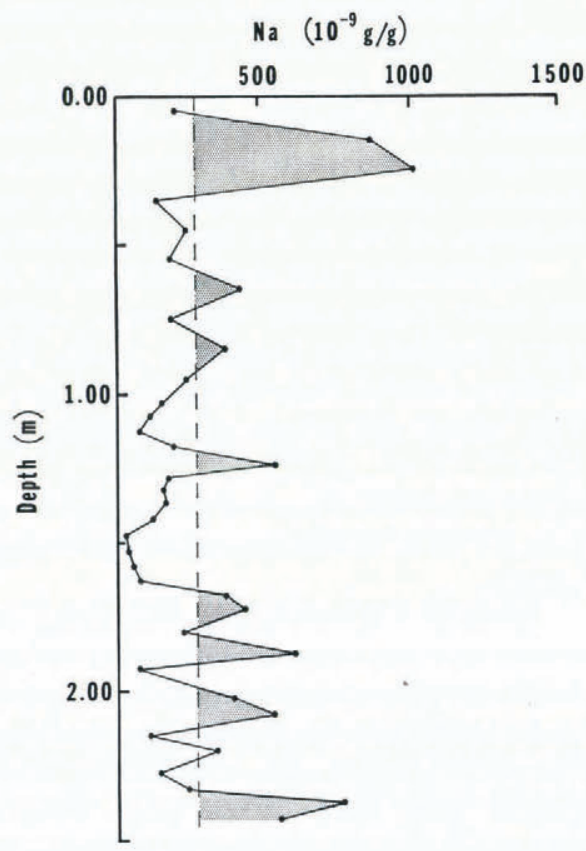

(d)

Fig. 2. Sodium concentrations in near-surface samples as a function of depth at a (top left). 7-9. $b$ (top right). C-7-I showing stratigraphically identified ice layers. $c$ (bottom left). C-7-I at a greater depth. $d$ (bottom right). Roosevelt Island dome. 
Sodium concentration peaks, which suggest an annual spacing, are also discernable at depth in the J-9 ice core. Figure 3 shows $\mathrm{Na}$ concentrations at a depth of about $66 \mathrm{~m}$ with a sampling interval of one centimeter. The annual layer thickness is determined to be about five centimeters of ice compared with the surface value of ten centimeters of ice. Although the present-day annual accumulation-rate up-stream from J-9 is fairly constant (Clausen and Dansgaard, 1977), the rate at the up-stream site and at the time of origin of the deeper ice may have been significantly different. Nevertheless, assuming that the change in annual layer thickness is solely due to vertical strain, a preliminary estimate of the average vertical strainrate from $\mathrm{Na}$ variations on four deep J-9 core samples is $9 \times 10^{-4} \mathrm{a}^{-1}$, slightly greater than the surface values of Thomas ( 1976 ). As many more data become available, it is expected that geographical and historical variations in accumulation-rates will be distinguished from the effects of vertical strain, and that chemical data will provide a supporting basis to delineate past vertical strain-rates.

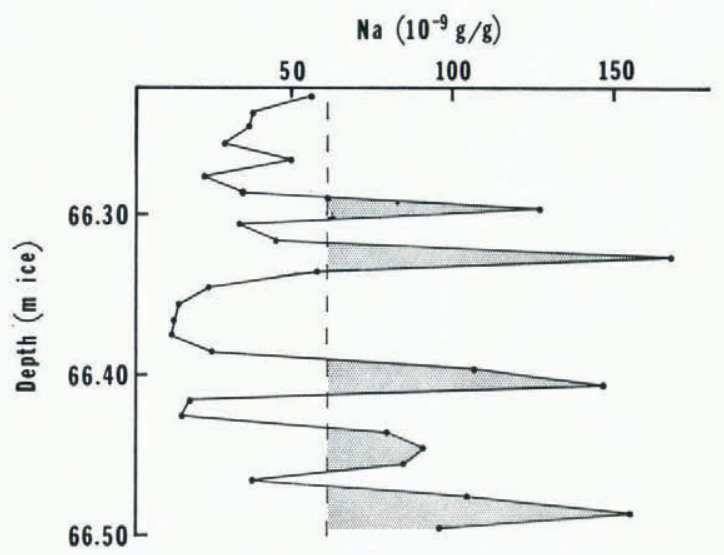

Fig. 3. Sodium concentrations against depth in the 7-9 1974 ice core.

\section{Geographigal VARiations}

Knowledge of the variation in Na concentration as a function of geographical position on the shelf can provide an important check on particle paths derived from glaciological and geophysical data utilizing various assumptions regarding past flow configurations of the ice shelf. The geographical distribution of $\mathrm{Na}$ concentrations on the Ross Ice Shelf is predominantly influenced by the distance of the site from the prime source of the element, the ocean. A similar distance-concentration relationship (Warburton and Linkletter, 1977) has been reported for continental areas (Junge, I963). Observed average values decrease sixfold from $600 \times \mathrm{IO}^{-9} \mathrm{~g} / \mathrm{g}$ at C-7-I to $100 \times 10^{-9} \mathrm{~g} / \mathrm{g}$ at $\mathrm{J}-9,450 \mathrm{~km}$ from the ice front. The upstream shelf origin of ice, now deep below the ice-shelf surface, may be estimated from a comparison of $\mathrm{Na}$ concentrations within ice cores and at up-stream surface locations.

The relationship between sea-salt concentration $C$ and distance in kilometers from the ocean $D$ may be expressed as

$$
C=C_{0} \exp \left(-\frac{D}{x}\right)
$$

after Junge and Gustafson (1957) and Toba (1965), where $C_{0}$ is the concentration at $D=\mathrm{o}$, and $x$ is a scale distance. The large seasonal and year-to-year variability in the Roosevelt Island dome and G-7-I concentrations indicates that a five- to ten-year average may be required for a representative average concentration. For the few long-term data now available, 
suitable values of $x$ and $C_{0}$ are $250 \mathrm{~km}$ and $600 \times 10^{-9} \mathrm{~g} / \mathrm{g}$ respectively (Fig. 4). The data of Warburton and Linkletter (1977) fit fairly well to the same form of the curve and scale distance but at about only half of the $C_{0}$ value. Perhaps this is due to the effect of seasonal variations and the short-time span represented in their samples. At the RISP Base Camp, where their sampling sequence covered approximately six years, Warburton and Linkletter (1977) reported an average $\mathrm{Na}$ concentration equivalent to that reported here for nearby $\mathrm{J}-9$, as shown by the overlapping points in Figure 4 .

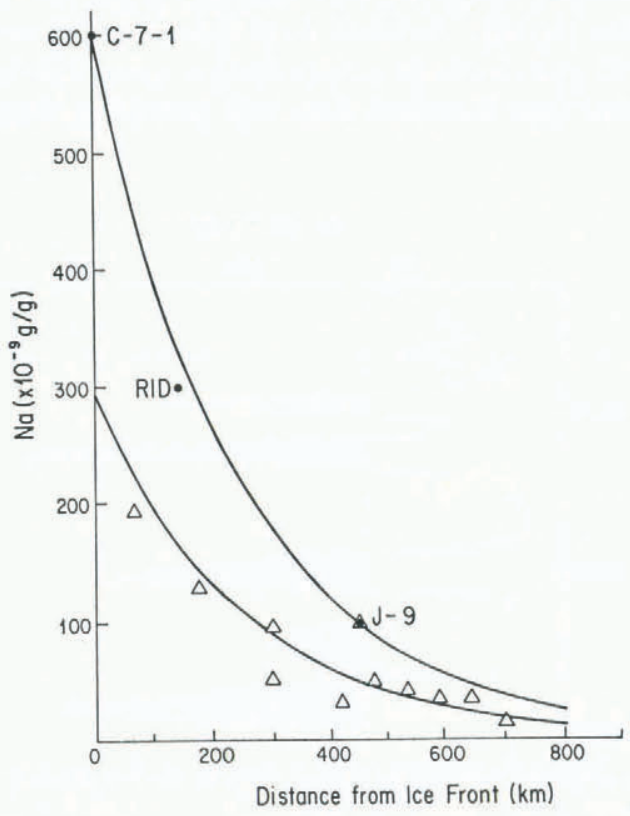

Fig. 4. Sodium concentrations on the Ross Ice Shelf as a function of distance from the ocean. Circles represent long-term data given in this report. Triangles represent data from Warburton and Linkletter (1977). The solid line was calculated from Equation (I) with $x=250 \mathrm{~km}$ and $C_{0}=6 \times \mathrm{IO}^{-7} \mathrm{~g} / \mathrm{g}$.

It should be mentioned that a number of factors may introduce complications into the simplistic pattern described here. Much of the net accumulation in the south-west portion of the shelf originated in East Antarctica with lower $\delta^{18} \mathrm{O}$ values (Clausen and Dansgaard, I977) and presumably much lower Na concentrations. Warburton and Linkletter (1977) have reported that rime and snow on the shelf have different chemical compositions, and that a measurable fraction of the total shelf accumulation may be in the form of rime. In addition, such secondary factors as mean annual temperature, local accumulation-rate, sea-ice extent, open-water polynyas, and volcanic aerosols from Mount Erebus may substantially affect the pattern of total concentrations and elemental ratios. Clearly the need exists to obtain more long-term concentration data at many sites on the Ross Ice Shelf.

\section{Glaciochemical Regimes}

In addition to ice that fell as snow on the shelf, the Ross Ice Shelf contains ice derived from the inland ice sheets of West and East Antarctica. It has been suggested (Herron and Langway, unpublished) that large areas of each of these ice sheets are homogeneous as far as sea-salt content is concerned, and that $\mathrm{Na}$ concentration is a useful criterion for identifying 
inland ice within the ice shelf. Table I gives recently reported concentrations of aluminum, alkali, and alkaline-earth elements in near-surface snow and ice-core samples from East and West Antarctica. Aluminum concentrations, which indicate continental dust input, are quite constant over the entire continent and on the shelf ice, including site J-9 where the average $\mathrm{Al}$ concentration was $0.7 \times 10^{-9} \mathrm{~g} / \mathrm{g}$. However, two distinct glaciochemical regimes may be identified using $\mathrm{Na}$ concentrations as a basis: the continental East Antarctic regime with about $\mathrm{IO}^{-8} \mathrm{~g} / \mathrm{g}$, and the continental West Antarctic regime where concentrations are a factor of three greater at about $30 \times 10^{-9} \mathrm{~g} / \mathrm{g}$. The Ross Ice Shelf may be considered as a third glaciochemical regime. The long-term surface snow and ice-core chemistry data indicate that $\mathrm{Na}$ concentrations on the shelf are consistently greater than $30 \times 10^{-9} \mathrm{~g} / \mathrm{g}$. Admixtures of local and wind-blown East Antarctic snow in the south-west section of the shelf may have resulted in lower Na concentrations. The average $\mathrm{Na}$ concentration in the $150-250 \mathrm{~m}$ depth interval of the Little America V (LAV) core was $29 \times 10^{-9} \mathrm{~g} / \mathrm{g}$ (Langway and others, I974), indicating that this ice is from the continental West Antarctic regime. The low variability in these samples and in the East Antarctic traverse data of Boutron and Lorius (1977) suggests that, within a given inland glaciochemical regime, distance from the ocean is not a primary factor in determining sea-salt concentrations.

Table I. Concentrations in the continental West Antarctic and continental East Antarctic regimes

\begin{tabular}{|c|c|c|c|c|c|c|c|}
\hline \multirow[b]{2}{*}{ Location } & \multicolumn{6}{|c|}{$\begin{array}{l}\text { Concentrations } \\
10^{-9} \mathrm{~g} / \mathrm{g}\end{array}$} & \\
\hline & Age & $\mathcal{N a}$ & $M g$ & $K$ & $\mathrm{Ca}$ & $A l$ & \\
\hline \multicolumn{8}{|l|}{ Continental West Antarctica } \\
\hline Byrd Station & I694-I $94^{2}$ A.D. & $3^{2}$ & $4 \cdot 4$ & I. 6 & 1.2 & & $\begin{array}{l}\text { Murozumi and others } \\
(1969)\end{array}$ \\
\hline Byrd Station & 2500-1 2000 B.P. & 28 & 2.4 & $3 \cdot 5$ & $3 \cdot 3$ & 1.5 & $\begin{array}{l}\text { Cragin and others } \\
\quad\left(\left[{ }^{\mathrm{c}}{ }_{1977])}\right.\right.\end{array}$ \\
\hline Byrd Station & I973-74 A.D. & 25 & 1.2 & I. 7 & I.I & 0.5 & $\begin{array}{l}\text { Boutron and Lorius } \\
\text { (1977) }\end{array}$ \\
\hline $\begin{array}{l}\text { Virgin Trench } \\
\text { (215 km NE. of Byrd) }\end{array}$ & 1965-66 A.D. & 20 & 1.5 & I. 1 & 0.8 & & $\begin{array}{l}\text { Murozumi and others } \\
(1969)\end{array}$ \\
\hline $\begin{array}{l}\text { Little American V ice core } \\
\quad(150-250 \mathrm{~m})\end{array}$ & & 29 & 2.6 & $5 \cdot 4$ & 2.2 & & $\begin{array}{l}\text { Langway and others } \\
\text { (1974) }\end{array}$ \\
\hline \multicolumn{8}{|l|}{ Continental East Antarctica } \\
\hline South Pole & I972-74 A.D. & 6.4 & 4.0 & 0.68 & $0.4 \mathrm{I}$ & 1.0 & $\begin{array}{l}\text { Boutron and Lorius } \\
(1977)\end{array}$ \\
\hline South Pole & 1969-74 A.D. & 10.0 & I. 5 & $0.7 \mathrm{I}$ & $\mathrm{I} .4$ & 0.9 & $\begin{array}{l}\text { Herron and Langway } \\
\text { (unpublished) }\end{array}$ \\
\hline South Pole & 1950-74 A.D. & 8.0 & 1.5 & 0.70 & 0.66 & 1.2 & $\begin{array}{l}\text { Boutron and others } \\
\text { (in press) }\end{array}$ \\
\hline Mizuho Plateau & & 13 & 2.3 & 0.9 & & & $\begin{array}{l}\text { Murozumi and Shimizu } \\
(1972)\end{array}$ \\
\hline \multicolumn{2}{|c|}{$\begin{array}{l}\text { Dumont d'Urville-Dome “C" traverse } \\
\text { ( }>\text { Ioo km from ocean) }\end{array}$} & $7 \cdot 4$ & 2.1 & I.o & 0.5 & 0.9 & $\begin{array}{l}\text { Boutron and Lorius } \\
\text { (1977) }\end{array}$ \\
\hline
\end{tabular}

The transition from snow which is chemically characteristic of the ice-shelf regime to snow with inland concentration levels probably occurs at some specific altitude. The vertical marine aerosol distribution over continents (Toba, 1965) suggests that the chemical transition zone may occur at an altitude of between 500 and $\mathrm{I}$ ooo $\mathrm{m}$. It is important to note that the location of this zone will be dependent upon, but will not necessarily be coincident with, the grounding line, which is the physical division between shelf and inland ice. In West Antarctica the $500 \mathrm{~m}$ elevation contour is as much as $200 \mathrm{~km}$ inland of the grounding line. Thus, the transition at a depth of $150 \mathrm{~m}$ in the Little America V core is better described as a glaciochemical transition rather than a shelf-inland transition. 


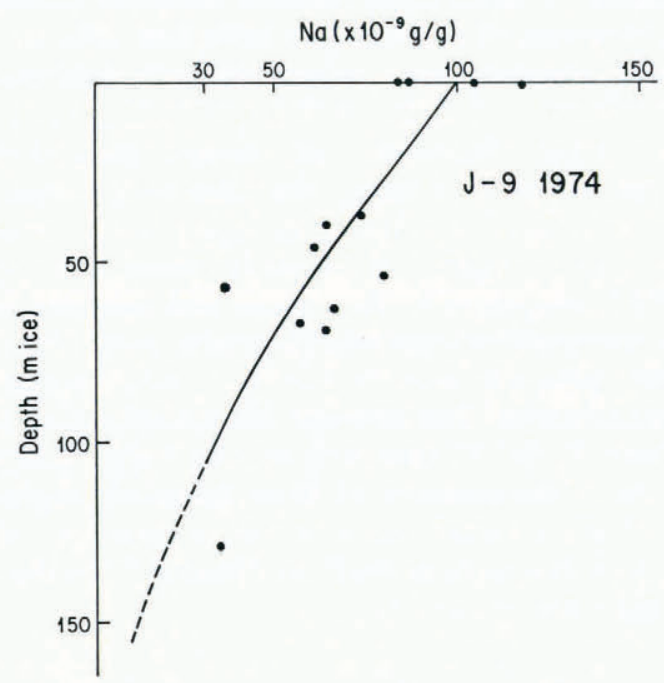

Fig. 5. Sodium concentration-depth profile in the 7-9 ice core. Solid line was calculated from Equation (4).

\section{Ross Ice Shelf cores}

To illustrate how these concepts may be applied, Figure 5 shows the measured Na concentrations in the J-9 core as a function of depth. Although the up-stream distance of origin $D$ of ice now at depth may be calculated from the data points using Equation (I), the scatter in the concentrations would make those distances difficult to interpret. Instead, a first approximation of the up-stream distance may be obtained from Equation (2),

$$
D=-\frac{v_{\mathrm{e}}}{\dot{\epsilon}} \ln \left(\mathrm{I}-\frac{\dot{\epsilon} d}{A}\right),
$$

modified from Haefeli (rg6r), where $d$ is the depth of ice in meters, $A$ is the annual accumulation-rate in $\mathrm{m} \mathrm{a}^{-1}, \dot{\epsilon}$ is the vertical strain-rate, and $v_{\mathrm{e}}$ is the effective ice velocity with $v_{\mathrm{e}}=|v| \sin \theta$, where $|v|$ is the magnitude of the velocity vector, and $\theta$ is the acute angle between the flow line and the concentration contour. Equation (2) is valid if the effective velocity, vertical strain-rate, and accumulation-rate are uniform with depth and distance up-stream. Over much of the ice shelf these assumptions are probably valid.

Solving Equation (I) for distance,

$$
D=x \ln \left(\frac{C_{0}}{C}\right),
$$

and setting Equation (2) and (3) equal to each other, we obtain an equation for the expected trend of $\mathrm{Na}$ with depth on the shelf:

$$
C=C_{\mathrm{o}}\left(\mathrm{I}-\frac{\dot{\boldsymbol{\epsilon}} d}{A}\right)^{v_{\mathrm{e}} / \dot{\epsilon} x} .
$$

The curve in Figure 5 was calculated from Equation (4) using values of $A=0 . \mathrm{I} \mathrm{m}$ of ice $\mathrm{a}^{-1}$ (Clausen and Dansgaard, 1977 ), $\dot{\epsilon}=5 \times 10^{-4} \mathrm{a}^{-1}$, and $|v|=400 \mathrm{~m}$ of ice $\mathrm{a}^{-1}$ (Thomas, 1976). A value of $v_{\mathrm{e}}=200 \mathrm{~m} \mathrm{a}^{-1}$, or $\theta=30^{\circ}$ was chosen to fit the chemistry data. A number of sets of values for $A, \dot{\epsilon}$, and $v_{\mathrm{e}}$ can be used in Equation (4) to derive similar depthconcentration curves, and it is not possible to derive a unique set of flow and accumulation- 
rate parameters from the chemistry data alone. However, it is possible to exclude unreasonable sets. For example, if the effective velocity were doubled, the curve would intersect the $\mathrm{Na}$ concentration of $3 \times 10^{-8} \mathrm{~g} / \mathrm{g}$ at a depth of only $63 \mathrm{~m}$ of ice; this clearly would conflict with the chemistry data.

The curve in Figure 5 intercepts the characteristic West Antarctic Na concentration of $3 \times 10^{-8} \mathrm{~g} / \mathrm{g}$ at a depth of about $105 \mathrm{~m}$ of ice or $130 \mathrm{~m}$ true depth. Alternate choices for the flow parameters that fit the $\mathrm{Na}$ data do not change this depth by more than ro $\mathrm{m}$. The intersection represents the glaciochemical transition from shelf ice to ice from the West Antarctic regime. The single sample from below $105 \mathrm{~m}$ of ice has a $\mathrm{Na}$ concentration of $3.4 \times 10^{-8} \mathrm{~g} / \mathrm{g}$ which is compatible with the indicated West Antarctic origin. If the surface position of the glaciochemical transition is at the $500 \mathrm{~m}$ elevation contour which is located about $450 \mathrm{~km}$ up-stream from J-9 along the flow line, then the age of J-9 ice at $\mathrm{I} 30 \mathrm{~m}$ true depth is about I roo years. This age is in good agreement with the depth-age relationship developed by Thomas (1976). On the other hand, ice that originated at the grounding line, which is approximately $200 \mathrm{~km}$ up-stream from J-9, should only be 500 years old. This is good evidence that the surface position of the glaciochemical transition is located near the $500 \mathrm{~m}$ elevation contour rather than near the grounding line.

Similar calculations have been performed for the Little America V core using an effective ice velocity of $25^{0} \mathrm{~m} \mathrm{a}^{-1}$ (U.S. Geological Survey, r972) and a vertical strain-rate of $8 \times 1^{-4}$ $\mathrm{a}^{-1}$. The surface concentration, which is not known, and the accumulation-rate were adjusted to fit the chemistry data of Langway and others (I974). Values obtained were $4^{8} \times \mathrm{ro}^{-8} \mathrm{~g} / \mathrm{g}$ for the surface concentration and $0.12 \mathrm{~m}$ of ice $\mathrm{a}^{-1}$ for the accumulation-rate. Near Little America V, accumulation-rates and strain-rates are significantly greater than given here, although up-stream values are comparable (Crary and others, I962).

In the Little America V core, the glaciochemical transition between West Antarctic and Ross Ice Shelf ice, determined from Figure 6, occurs at a depth of about $130 \mathrm{~m}$ of ice or I $55 \mathrm{~m}$ true depth. The origin of ice at this depth as calculated from the flow data given above is $620 \mathrm{~km}$. The distance from Little America V to the $500 \mathrm{~m}$ elevation contour is about $550 \mathrm{~km}$, whereas the grounding line is only $320 \mathrm{~km}$ up-stream from Little America V (Crary and others, 1962). This provides further evidence that the glaciochemical transition occurs

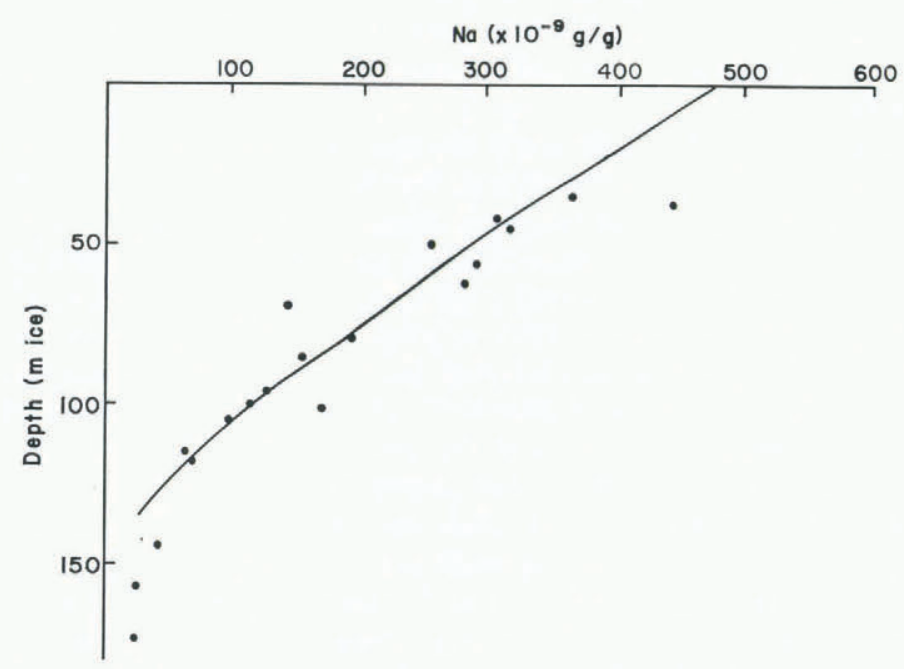

Fig. 6. Sodium concentration-depth profile in the Little America V ice core. Data is from Langway and others, 1974. Solid curve was calculated from Equation (4). 
near the $500 \mathrm{~m}$ elevation contour. Dansgaard and others (1977) compared the stable oxygenisotope data from a location near the grounding line with the profile from the Little America V core. They suggested that the shelf inland transition could be as shallow as $120 \mathrm{~m}(95 \mathrm{~m}$ of ice) but not deeper than $180 \mathrm{~m}$. The origin of ice at the $120 \mathrm{~m}$ depth is calculated to be 3 Io $\mathrm{km}$ up-stream, which is very close to the grounding line.

Thus, the Little America core is interpreted as containing shelf ice to a depth of about $120 \mathrm{~m}$, and ice derived from inland of the $500 \mathrm{~m}$ elevation contour below a depth of $150 \mathrm{~m}$. The change in ice texture and fabric reported to occur at a depth of $150 \mathrm{~m}$ (Gow, 1970) appears to be associated with ice well inland of the grounding line. Our interpretation is not compatible with the particle-path calculations of Crary and others (1962) which indicate that ice from the shelf-inland transition would be located at a depth of about $230 \mathrm{~m}$. While a relatively shallow glaciochemical transition in the Little America V core could be caused by a surge of the West Antarctic ice sheet feeding Little America V, this does not appear to be the case. Such a surge would be marked by a discontinuity in the form of a sharp change in the slope of the depth-Na-concentration curve which is not apparent in the data. Rather, the data suggest that there is a regular variation in up-stream distance of origin with depth in the core, and that the up-stream distances calculated by Crary and others (1962) may all be too low by as much as a factor of two. The preceding interpretation may be critically evaluated when the particle-path calculations of the Ross Ice Shelf Glaciological and Geophysical Survey are completed, and when stable oxygen-isotope and surface-chemistry data are available for sites up-stream of Little America V.

\section{SumMARY AND GONCLUSIONS}

Detailed chemical analysis shows that seasonal variations in $\mathrm{Na}$ concentrations are detectable in cores from the Ross Ice Shelf. The seasonal maximum in concentration appears to occur in the winter, as it does in Greenland cores. The discovery of seasonal variations makes possible a rapid determination of recent annual accumulation-rates. Seasonal chemistry measurements at site J-9 are supported by the accumulation values of Clausen and Dansgaard (1977) which were generally lower than previously reported values. The possibility of the determination of annual layer thicknesses at depth also exists; however, the low accumulationrates and relatively high vertical strain-rates present on the shelf result in very thin annual layers at moderate depths, and the reliability of similar measurements has been questioned (Johnsen and others, 1977).

A model is proposed for the large-scale decrease in $\mathrm{Na}$ concentration with increasing distance from the ocean. When combined with the chemical profile of an ice core, the model may be used to estimate the up-stream origin of deep ice within the shelf. The model may also be used to produce depth-Na curves expected from given flow and accumulation parameters.

The large seasonal and annual variability in $\mathrm{Na}$ concentration indicates that a representative mean concentration for a given location will require a five- to ten-year sampling interval. Snow originating in East Antarctica which is then blown onto the shelf complicates the pattern, particularly in the south-west section of the shelf. The relative amounts of snow of local and of distant origin might be determined once the general pattern of accumulation-rates, and stable isotope and sea-salt concentrations are identified. Average annual $\mathrm{Na}$ concentrations will be a function of parameters such as mean annual or winter temperature and winter storminess. The latitudinal extent of dispersed sea ice is probably important through the inhibition of sea-spray aerosol generation. The $\mathrm{Na}$ and $\mathrm{Mg}$ concentrations measured in two Greenland ice cores (Langway and others, I974; Herron and others, 1977) are significantly below average during the Little Ice Age (c. I 400-I 850 A.D.). The greater predominance of sea salt as an aerosol source on the shelf and the lack of long-term Antarctic meteorological data 
suggest that continuous measurement of Na concentrations on Ross Ice Shelf cores will be of significant value.

The glaciochemical regimes concept suggests that $\mathrm{Na}$ concentration may be used to identify the origin of ice located within the Ross Ice Shelf. It has been shown that East Antarctic snow averages about $10^{-9} \mathrm{~g} \mathrm{Na} \mathrm{g}^{-1}$, West Antarctic snow averages about $3 \times 10^{-8}$ $\mathrm{g} \mathrm{Na} \mathrm{g}^{-1}$, and average concentrations of shelf snow are generally much greater than $3 \times 10^{-8}$ $\mathrm{g} \mathrm{Na} \mathrm{g}^{-1}$. Recent measurements in East Antarctica (Boutron and others, in press) confirm the large-scale homogeneity of $\mathrm{Na}$ concentrations at distances from 220 to $\mathrm{I} 070 \mathrm{~km}$ from the coast. Similar traverse data are needed for West Antarctica to confirm the suggested homogeneity and to delineate the surface position of the glaciochemical transition.

The up-stream positions of the glaciochemical transitions in the J-9 and Little America V cores appear to coincide roughly with the $500 \mathrm{~m}$ elevation contour, which is as much as $200 \mathrm{~km}$ inland of the grounding line. The depth of this transition in the LAV core is considerably shallower than predicted by Crary and others ( 1962 ), but the regularity of the Na concentration decrease with depth indicates that this discrepancy is not due to a surge. Rather, it appears that all of the previously calculated up-stream distances are low by as much as a factor of two.

If a surge of West Antarctic ice has occurred within the last few thousand years, it is likely that the flow line on the Ross Ice Shelf separating East and West Antarctic ice (Fig. I) was farther to the west than now. A deep core taken from the west side of the present flow line and east of the "surge" flow line should contain shelf ice underlain by predominantly East Antarctic ice . At the appropriate depth-age interval of the surge, however, there would be West Antarctic ice. Such an interval would be identifiable in the chemical profile.

\section{Acknowledgements}

The authors would like to thank J. H. Cragin, G. A. Klouda, and D. Watroba for field and laboratory assistance.

\section{REFERENCES}

Boutron, C., and Lorius, C. 1977. Trace element content in East Antarctica snow samples. [Union Géodésique et Géophysique Internationale. Association Internationale des Sciences Hydrologiques. Commission des Neiges et Glaces.] Symposium. Isotopes et impuretés dans les neiges et glaces. Actes du colloque de Grenoble, août/septembre, 1975, p. 164-71. (IAHS-AISH Publication No. I 18. )

Boutron, C., and others. In press. Composition of aerosols deposited in snow at the South Pole, time dependency and sources, by C. Boutron, S. Martin, and C. Lorius. [Paper presented at the ninth International Conference on Atmospheric Aerosols, Condensation and Ice Nuclei, held at Galway, Ireland, 2 I-27 September 1977.]

Bull, C. B. B. I97I. Snow accumulation in Antarctica. (In Quam, L. O., ed. Research in the Antarctic. A symposium presented at the Dallas meeting of the American Association for the Advancement of Science-December 1968. Washington, D.C., American Association for the Advancement of Science, p. $367-421$.)

Clausen, H. B., and Dansgaard, W. 1977. Less surface accumulation on the Ross Ice Shelf than hitherto assumed. [Union Géodésique et Géophysique Internationale. Association Internationale des Sciences Hydrologiques. Commission des Neiges et Glaces.] Symposium. Isotopes et impuretés dans les neiges et glaces. Actes du colloque de Grenoble, août/septembre 1975 , p. $172-76$. (IAHS-AISH Publication No. 118 .)

Cragin, J. H., and others. [ ${ }^{{ }^{1}}$ 977.] Interhemispheric comparison of changes in the composition of atmospheric precipitation during the Late Cenozoic Era, [by] J. H. Cragin, M. M. Herron, C. C. Langway, Jr, and G. [A.] Klouda. (In Dunbar, M. J., ed. Polar Oceans. Calgary, Alberta, Arctic Institute of North America, p. 61 7-31.)

Crary, A. P., and others. 1962. Glaciological studies of the Ross Ice Shelf, 1957-1960, by A. P. Crary, E. S. Robinson, H. F. Bennett, and W. W. Boyd, Jr. IGY Glaciological Report Series (New York), No. 6.

Dansgaard, W., and others. 1977. Stable isotope profile through the Ross Ice Shelf at Little America V, Antarctica, 
[by] W. Dansgaard, S. J. Johnsen, H. B. Clausen, C. U. Hammer, and C. C. Langway, Jr. [Union Géodésique et Géophysique Internationale. Association Internationale des Sciences Hydrologiques. Commission des Neiges et Glaces.] Symposium. Isotopes et impuretés dans les neiges et glaces. Actes du colloque de Grenoble, août/septembre 1975, p. 322-25. (IAHS-AISH Publication No. 1 i 8.)

Giovinetto, M. B., and Zumberge, J. H. 1967. The ice regime of the eastern part of the Ross Ice Shelf drainage system. Union de Géodésie et Géophysique Internationale. Association Internationale d'Hydrologie Scientifique. Assemblée générale de Berne, 25 sept.-7 oct. I967. [Commission de Neiges et Glaces.] Rapports et discussions, p. 255-66. (Publication No. 79 de l'Association Internationale d'Hydrologie Scientifique.)

Gow, A. J. 1970. Deep core studies of the crystal structure and fabric of Antarctic glacier ice. U.S. Cold Regions Research and Engineering Laboratory. Research Report 282.

Haefeli, R. 196r. Contribution to the movement and form of ice sheets in the Arctic and Antarctic. Fournal of Glaciology, Vol. 3, No. 30, p. II33-50.

Heap, J. A., and Rundle, A. S. Ig64. Snow accumulation on the Ross Ice Shelf, Antarctica. (In Mellor, M., ed. Antarctic snow and ice studies II. Washington, D.C., American Geophysical Union, p. Ir9-25. (Antarctic Research Series, Vol. 2.))

Herron, M. M., and Langway, C. C., jr. 1978. Seasonal variations in Ross Ice Shelf precipitation chemistry. Eos. Transactions, American Geophysical Union, Vol. 59, No. 4, p. 308. [Abstract.]

Herron, M. M., and Langway, C. C., jr. Unpublished. Glaciological regimes of the Ross Ice Shelf, Antarctica. [Presented to the SCAR Working Group on Glaciology, Mendoza, Argentina, I9 October 1976.]

Herron, M. M., and others. 1977. Atmospheric trace metals and sulfate in the Greenland ice sheet, [by] M. M. Herron, C. C. Langway, Jr, H. V. Weiss, and J. H. Cragin. Geochimica et Cosmochimica Acta, Vol. 41, No. 7, p. $9^{1} 5^{-20}$.

Hughes, T. J. 1973. Is the West Antarctic ice sheet disintegrating? Fournal of Geophysical Research, Vol. 78, No. 33, p. 7884-910.

Johnsen, S. J., and others. 1972. Oxygen isotope profiles through the Antarctic and Greenland ice sheets, [by] S. J. Johnsen, W. Dansgaard, H. B. Clausen, C. C. Langway, Jr. Nature, Vol. 235, No. 5339, p. 429-34.

Johnsen, S. J., and others. 1977. Microparticles in "Byrd" Station ice core: further comments on the paper by L. G. Thompson, W. L. Hamilton, and C. [B. B.] Bull, [by] S. J. Johnsen, C. U. Hammer, N. Reeh, W. Dansgaard. Fournal of Glaciology, Vol. 18 , No. 78, p. 164 . [Letter.]

Junge, C. E. I963. Air chemistry and radioactivity. New York, Academic Press.

Junge, C. E., and Gustafson, P. E. 1957. On the distribution of sea salt over the United States and its removal by precipitation. Tellus, Vol. 9, No, 2, p. 164-73.

Koide, M., and Goldberg, E. D. 1971. Atmospheric sulfur and fossil fuel combustion. Journal of Geophysical Research, Vol. 76 , No. 27, p. 7689-96.

Koide, M., and others. 1979. Depositional history of artificial radionuclides in the Ross Ice Shelf, Antarctica, [by] M. Koide, R. Michel, E. D. Goldberg, M. M. Herron, and C. C. Langway, Jr. Earth and Planetary Science Letters, Vol. 44, No. 2, p. 205-33.

Langway, C. C., jr, and Herron, M. M. 1977. Polar ice core analysis. Antarctic Journal of the United States, Vol. 12, No. 4 , p. $152-54$

Langway, C. C., jr, and others. 1974. Chemical profile of the Ross Ice Shelf at Little America V, Antarctica, by C. C. Langway, Jr, M. M. Herron, and J. H. Cragin. Fournal of Glaciology, Vol. 13, No. 69, p. 431-35.

Langway, C. C., jr, and others. I 977 . Seasonal variations of chemical constituents in annual layers of Greenland deep ice deposits, [by] C. C. Langway, Jr, G. A. Klouda, M. M. Herron, and J. H. Cragin. [Union Géodésique et Géophysique Internationale. Association Internationale des Sciences Hydrologiques. Commission des Neiges et Glaces.] Symposium. Isotopes et impuretés dans les neiges et glaces. Actes du colloque de Grenoble, août/septembre 1975, p. 302-06. (IAHS-AISH Publication No. I18.)

Murozumi, M., and Shimizu, H. I972. Chemical constituents in the surface snow cover on the Mizuho Plateauwest Enderby Land area, East Antarctica, 1970-1971. (In Ishida, T., ed. Glaciological research program in Mizuho Plateau - west Enderby Land. Part I, I969-197I. Tokyo, Polar Research Center, National Science Museum, p. 132-34. (Japanese Antarctic Research Expedition. JARE Data Reports, No. I7 (Glaciology).))

Murozumi, M., and others. 1969 . Chemical concentrations of pollutant lead aerosols, terrestrial dusts, and sea salts in Greenland and Antarctic snow strata, [by] M. Murozumi, T. J. Chow, and C. Patterson. Geochimica et Cosmochimica Acta, Vol. 33, No. I0, p. 1247-94.

Rand, J. H. 1975. Ioo-meter cores from the South Pole and the Ross Ice Shelf. Antarctic Fournal of the United States, Vol. 10, No. 4, p. 150-5I.

Rand, J. H. 1977. Ross Ice Shelf Project drilling, October-December 1976. Antarctic Fournal of the United States, Vol. 12, No. 4, p. 150-51.

Stauffer, B., and Moell, M. 1977. Geochemical and isotope studies, Ross Ice Shelf Project. Antarctic Fournal of the United States, Vol. 12, No. 4, p. $145-46$.

Thomas, R. H. 1976. Thickening of the Ross Ice Shelf and equilibrium state of the West Antarctic ice sheet. Nature, Vol. 259 , No. 5540 , p. 18o-83.

Toba, Y. I 965 . On the giant sea-salt particles in the atmosphere. I. General features of the distribution. Tellus, Vol. 17, No. I, p. I 3 I-45.

Tsunogoi, S. 1975. Sea salt particles transported to the land. Tellus, Vol. 27, No. 1, p. $51-58$.

U.S. Geological Survey. 1972. Map of the Ross Ice Shelf. Washington, D.C., U.S. Geological Survey and National Science Foundation. [Scale I : I ooo ooo, also I : 2 I 88 800.]

Warburton, J. A., and Linkletter, G. O. 1977. Precipitation-forming mechanisms and the chemistry of precipitation on the Ross Ice Shelf, Antarctica. [Union Géodésique et Géophysique Internationale. Association Internationale des Sciences Hydrologiques. Commission des Neiges et Glaces.] Symposium. Isotopes et impuretés dans les neiges et glaces. Actes du colloque de Grenoble, août/septembre 1975, p. 88-94. (IAHS-AISH Publication No. I 18.) 


\section{DISGUSSION}

T. J. Hughes: Do you plan to do any further work of this type to determine whether the line dividing East and West Antarctic ice has shifted over the last 2000 years?

M. M. Herron: Yes. We hope to recover a series of $200 \mathrm{~m}$ deep cores from locations near the present drainage divide.

C. R. Bentley: Why do the peaks in sodium associated with sea spray occur in winter and early spring when the open water is farthest away, even at C-7 which is close to summer-time open water?

Herron: The winter maximum in sea spray is also found in Greenland cores where oxygenisotope data are available for comparison. The simplest explanation is that sea-salt aerosol production is greater due to greater storminess in winter. The effect of sea ice may be important as well.

D. A. Fisher: Does not using sodium concentration as a tracer for the origin of ice assume that there are no climatic trends in sodium deposited inland?

Herron: Yes. Although this has not been studied in West Antarctica, sodium concentrations along the traverse from Dumont d'Urville to Dome C, measured by the French, are quite constant over a $\mathrm{I}$ ooo $\mathrm{km}$ distance, despite considerable changes in accumulation-rate and temperature. It is hoped that sodium concentrations may well prove a valuable climatic index, and that any past changes can be accounted for.

P. MAGKInNon: What is your justification for assuming a constant and different concentration fallout for sodium with respect to time for East and West Antarctica?

Herron: As shown in Table I, measured values are quite different for the two large areas. The data for West Antarctica are still a bit sparse.

Mackinnon: How does the variation, if it occurs, affect your differentiation between East and West Antarctic ice?

Herron: We have detected a small decrease in sea-salt concentrations in two Greenland cores during the Little Ice Age, so the possibility is real. We can only assume that concentrations in both West and East Antarctica will decrease simultaneously. Short periods of general cooling or warming will appear as small oscillations on a profile of sodium with depth. We expect that Wisconsin Age ice, if it exists in the Ross Ice Shelf, will have elevated concentrations of $\mathrm{Al}$ and $\mathrm{Si}$ among other elements, as is the case in the Byrd core. 